\author{
ELWIRA KACZYŃSKA, KRZYSZTOF TOMASZ WITCZAK \\ Uniwersytet Łódzki
}

\title{
GRECKIE NAZWY DUŻYCH ZWIERZĄT MORSKICH W ŚWIETLE RELACJI ELIANA (O NATURZE ZWIERZĄT IX 49)
}

\begin{abstract}
Kaczyńska Elwira, Witczak Krzysztof Tomasz, Greckie nazwy dużych zwierząt morskich w świetle relacji Eliana (O naturze zwierzat IX 49) (Ancient Greek Names of Large Sea Animals in the Light of Aelian's Testimony [De natura animalium IX 49]).

The paper analyzes chapter IX 49 of Aelian's De natura animalium, devoted to the largest sea animals. It is accompanied by a Polish translation and appropriate comments. Aelian provides numerous Ancient Greek names for large sharks and sea mammals, including the "sea lion," hammer-headed shark, "sea leopard", whales, sawfish, malthe, "sea ram", "sea hyena" and "sea dogs". The names are explained from the point of view of semantic motivation; some new identifications of sea monsters are suggested as well.
\end{abstract}

Keywords: animal terminology; etymology; Greek language; vocabulary; word formation.

W rozdziale 49 dziewiątej księgi dzieła $O$ właściwościach zwierząt (gr.

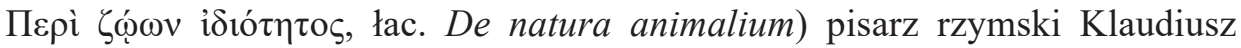
Elian z Praeneste (II-III w. n.e.) wylicza największe morskie stworzenia (gr. $\tau \grave{\alpha}$

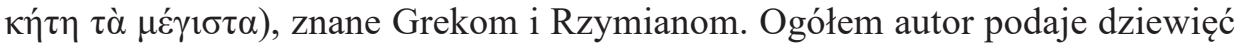

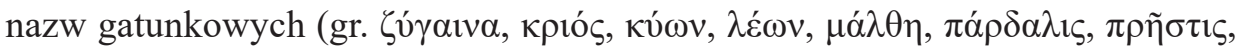

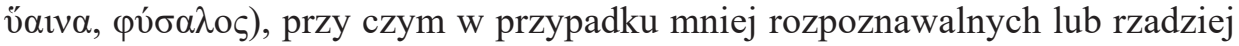

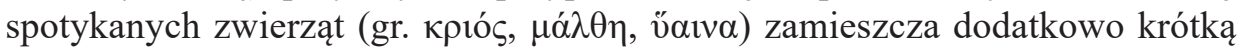
ich charakterystykę. Zdaniem Alwyna Fabera Scholfielda, bezspornie można

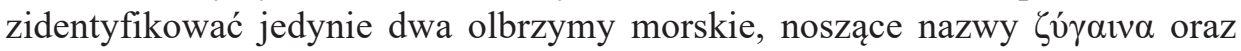

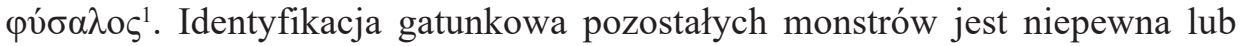
dyskusyjna. W niniejszej pracy chcielibyśmy podjąć rozważania nad gatunkową przynależnością wymienionych przez Eliana stworzeń.

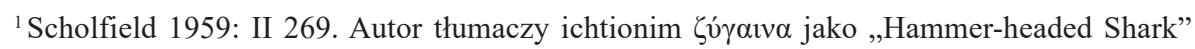
oraz zoonim $\varphi v ́ \sigma \alpha \lambda o r$ jako ,great Whales”, a w przypisie dodaje: „The only animals in the list that have been certainly identified". 


\section{TEKST ORYGINALNY I TŁUMACZENIE}

Polskiemu czytelnikowi dzieło Klaudiusza Eliana znane jest w wyborze, obejmującym około $65 \%$ oryginalnego tekstu². Niestety, subiektywna selekcja fragmentów, przygotowana przez prof. Annę Marię Komornicką, nie uwzględnia rozdziału IX 49 dotyczącego zwierząt morskich ogromnych rozmiarów³

Poniżej prezentujemy oryginalny tekst grecki i jego polski przekład:

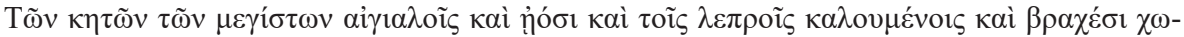

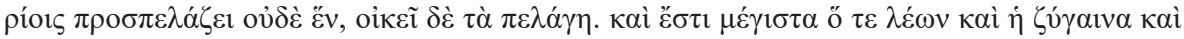

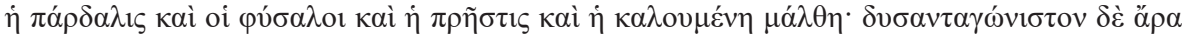

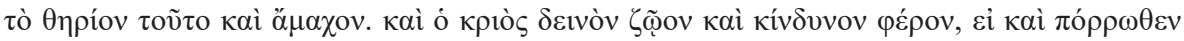

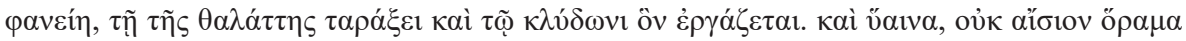

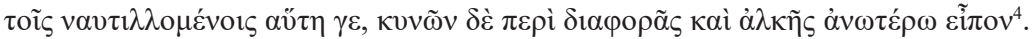

(Ael. NA I 55)

Żadne z ogromnych zwierząt morskich nie zbliża się do wybrzeży i plaż, ani też do miejsc skalistych czy płytkich wód. Zamieszkują one otwarte przestrzenie morskie. Do największych zwierząt morskich należą: „lew morski” (léōn), ryba młot (dzýgaina), „lampart morski” (párdalis), wieloryby (phýsaloi), a także ryba piła (prẽstis) i tak zwana málthē. To ostatnie stworzenie jest trudne do pokonania nawet wtedy, gdy nie walczy. „Baran morski” (krīós) jest także strasznym zwierzęciem, niosącym niebezpieczeństwo, nawet jeśli w oddali się pojawi, na skutek wzburzenia morza i falowania, które [przy wynurzaniu się] wywołuje. Również „hiena morska" (hýaina) stanowi widok niepomyślny dla żeglarzy. O różnych gatunkach rekinków (,psów morskich”) i ich sile wcześniej już opowiedziałem5

(tłum. własne)

\section{IDENTYFIKACJA OLBRZYMICH STWORZEŃ MORSKICH}

Nasze rozważania zaczniemy od objaśnienia znaczenia i etymologii podstawowego (ogólnego) terminu кñ os, użytego przez Eliana na określenie potworów morskich, następnie poddamy analizie etymologiczno-semantycznej poszczególne nazwy gatunkowe oraz zaproponujemy identyfikację morskich zwierząt monstrualnych rozmiarów.

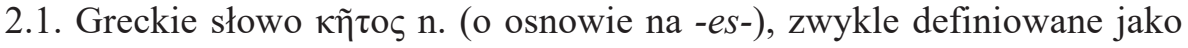
'potwór morski, ogromna ryba' ${ }^{6}$, pojawia się już w poematach Homera ${ }^{7}$. Zwykle

${ }^{2}$ Komornicka 2005: 22.

${ }^{3}$ Rozdziału IX 49 nie uwzględnia też artykuł opublikowany na łamach „Meandra”, zawierający 25 opowiastek zwierzęcych (Komornicka 2004: 391-403).

${ }^{4}$ Scholfield 1959: III 266-268; Maspero 1998: 564.

${ }^{5}$ Zob. w Ael. NA I 55, gdzie autor wyróżnia trzy gatunki rekinków. Por. także tłumaczenie polskie: Komornicka 2005: 38-39.

${ }^{6}$ Abramowiczówna 1960: II 660; Jurewicz 2000: 534.

${ }^{7}$ Za wydaniem: Hom. Il. XX 147; Hom. Od. IV 446, 452 (o fokach); Hom. V 421; XII 97. 
odnosi się do dużych ssaków morskich, takich jak walenie, delfiny i foki, jak i do ryb wielkich rozmiarów, zwłaszcza rekinów, wyjątkowo także do tuńczy-

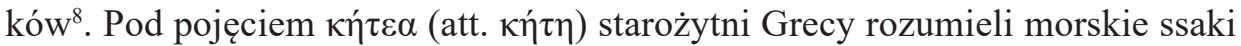
żyworodne oraz duże ryby jajożyworodne (w opozycji do ryb jajorodnych) ${ }^{9}$.

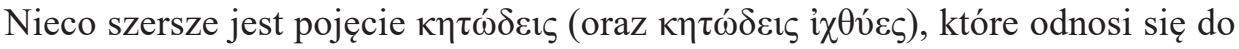
bardzo dużych ryb jajorodnych, zarówno morskich, jak i słodkowodnych ${ }^{10}$. Leksykon Suda (X w. n.e.) podaje następującą definicję terminu:

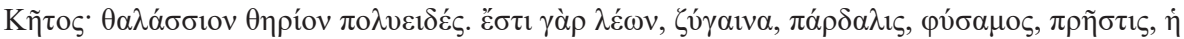

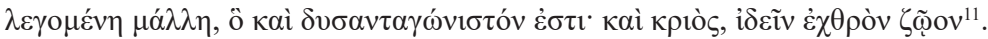

Kẽtos: zwierzę morskie o różnym wyglądzie. Istnieje bowiem „lew morski”, ryba młot, „lampart morski”, wieloryb (phýsamos), ryba piła, tak zwana málle, która jest trudna do pokonania, a także „baran morski”, złowrogie zwierzę już na pierwszy rzut oka (tłum. własne).

Nie ulega najmniejszej wątpliwości, że twórca bizantyńskiego leksykonu

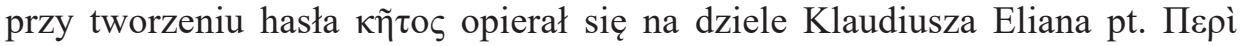

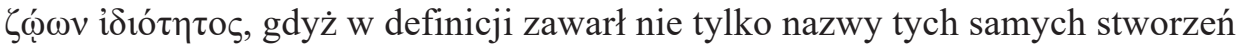
morskich, ale też wymienił je w identycznej kolejności. Nieco obszerniejszą listę potworów morskich zamieścił Oppian z Korykos (II w. n.e.) w eposie dy-

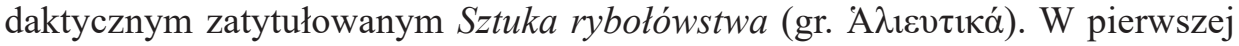
księdze epopei (w. 360-373) wymienił on wśród zwierząt morskich o monstru-

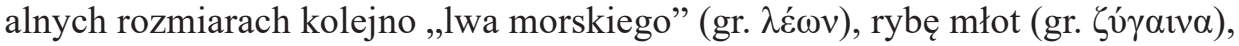

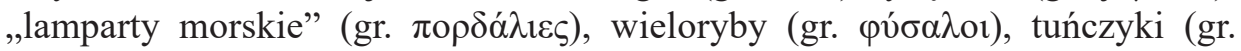

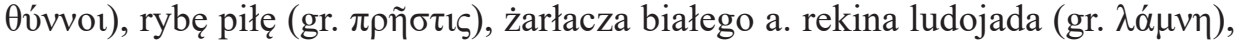

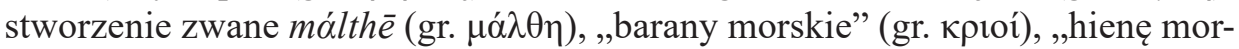

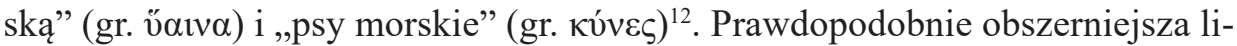
sta morskich olbrzymów, przedstawiona przez Oppiana, była pierwowzorem dla Klaudiusza Eliana, który dokonał selekcji materiału, pomijając m.in. tuńczyki $\mathrm{z}$ rodziny makrelowatych (Scombridae).

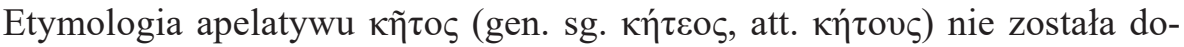
tychczas objaśniona. Nie jest wykluczone, że wyraz grecki został zapożyczony z jakiegoś przedgreckiego (śródziemnomorskiego) substratu ${ }^{13}$.

2.2. Jako pierwszy na liście potworów morskich, zaprezentowanej przez Klaudiusza Eliana i innych autorów, został wymieniony „lew morski” (gr. $\lambda \varepsilon \dot{\varepsilon} \omega v)$, który, zdaniem Thompsona, jest niezidentyfikowanym potworem mor-

\footnotetext{
${ }^{8}$ Liddell, Scott 1996: 949-950. Zob. także Kurek 2010: 55-62.

${ }^{9}$ Chrone-Vakalopoulos, Vakalopoulos 2008: 153-154; Kokoszko 2005: 156.

${ }^{10}$ Kokoszko 2005: 155-156.

${ }^{11}$ Adler 1967: 112.

${ }^{12}$ Kurek 2010: 57. Por. też Schneider 1813: 82.

${ }^{13}$ Beekes 2010: 690-691 („etym Unexplained. Probably a Pre-Greek word”).
} 
skim („An unknown sea-monster”14). Oprócz Eliana, „lwa morskiego” wymie-

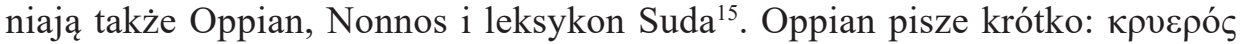

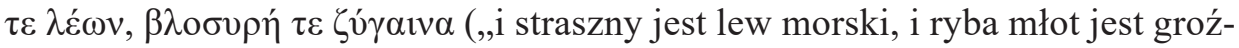
na"). Elian opisując stworzenia morskie, występujące wokół wyspy Cejlon (Sri Lanki), znanej w świecie grecko-rzymskim pod nazwą Taprobanē, wyszczególnia morskie zwierzęta mające ,głowy lwów, lampartów, wilków i baranów”

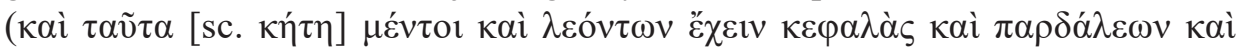

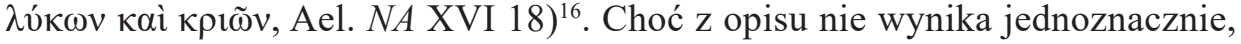
czy chodzi o te same gatunki morskich stworzeń, które występują w Morzu

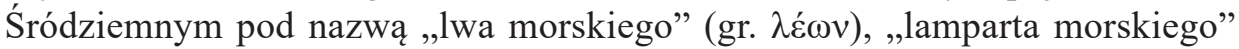

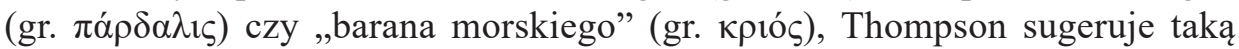
właśnie relację ${ }^{17}$.

O ile nam wiadomo, dotychczas w literaturze przedmiotu nie zaproponowano identyfikacji „lwa morskiego”. Autorzy renomowanych słowników języka greckiego nie podają identyfikacji gatunkowej potwora morskiego zwanego

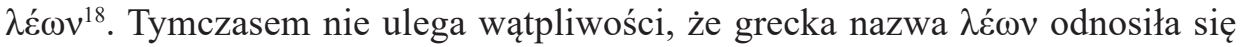
do rekina olbrzymiego, zwanego też długoszparem albo rekinem słonecznym (Cetorhinus maximus Gunnerus, syn. Selache maxima, Squalus maximus Gunnerus), jedynego, obecnie żyjącego przedstawiciela rodziny długoszparowatych (Cetorhinidae). Rekin olbrzymi jest gatunkiem kosmopolitycznym, licznie występującym w zachodniej części Morzu Śródziemnomorskiego, spotykanym także w akwenie Morza Jońskiego i Egejskiego ${ }^{19}$.

Cztery przesłanki przemawiają za wspomnianą identyfikacją:

Po pierwsze, długoszpar (Cetorhinus maximus Gunnerus), jest największym rekinem spośród obecnie żyjących w basenie Morza Śródziemnego. Dorosły osobnik osiąga rozmiary od 7 do 12 metrów (maksymalnie do $15 \mathrm{~m}$ ) i może ważyć nawet 4,5 tony. Z uwagi na imponującą wielkość i przerażający wygląd rekin ten mógł być kojarzony z lwem ${ }^{20}$.

Po drugie, rekin olbrzymi charakteryzuje się pięcioma potężnymi i długimi otworami skrzelowymi, sięgającymi od wierzchu głowy aż po okolice płetw piersiowych, z powodu których nadano mu alternatywną nazwę długoszpar.

${ }^{14}$ Thompson 1936: 150.

${ }^{15}$ Za wydaniem: Opp. H. I 367; Nonn. D. I 273.

${ }^{16}$ Por. Scholfield 1959: III 284; Maspero 1998: 910.

${ }^{17}$ Thompson 1936: 151.

${ }^{18}$ Zob. Abramowiczówna 1962: III 28 (,jakiś morski potwór”); Liddell, Scott 1996: 1043 (,a sea-monster”); Montanari 2003: 1183 („,mostro marino”).

${ }^{19}$ Rutkowicz 1982: 134-135; Terofal, Militz 1996: 14-15.

${ }^{20}$ Należy tu podkreślić, że rekin olbrzymi nie jest bynajmniej największym potworem morskim, jakiego znali Grecy i Rzymianie, gdyż walenie (zarówno zębowce, jak i fiszbinowce) znacznie przewyższają go rozmiarami. Przypomnijmy jednak, że lew (Pantera leo L.) także nie należy do największych okazów fauny lądowej. Większe od niego są np. słonie lub tygrysy, a mimo to lew już w starożytności (od czasów Ezopa) był uważany za króla zwierząt. 


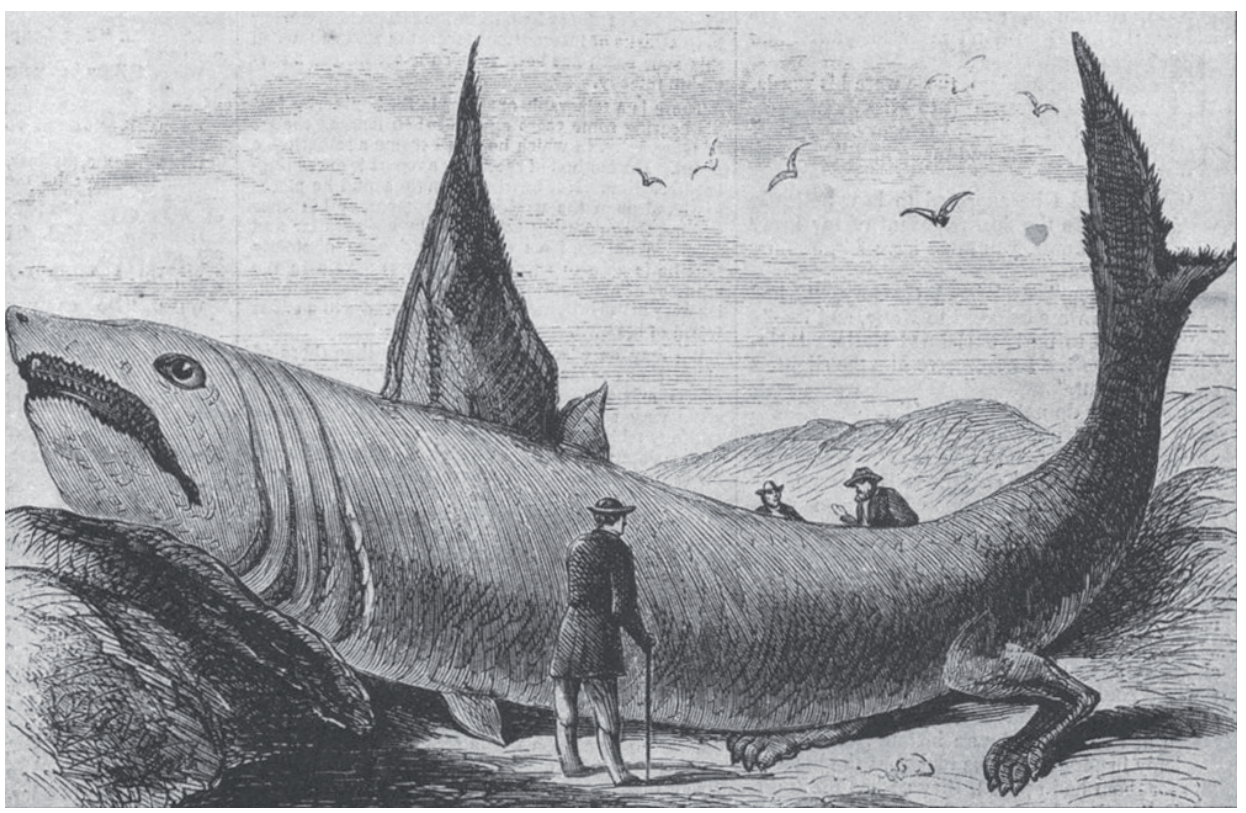

Ilustr. 1. Wyrzucony na ląd rekin olbrzymi, zwany też długoszparem (Cetorhinus maximus Gunnerus), przedstawiony przez rysownika czasopisma „Harper's Weekly” (1868) z lwimi łapami.

Źródło: Wikimedia Commons. Domena publiczna.

Szeroki pas szczelin skrzelowych, otaczających głowę rekina olbrzymiego, przywodzi na myśl lwią grzywę. Jest to doskonale widoczna i niewątpliwie najbardziej rozpoznawalna cecha tej monstrualnej ryby.

Po trzecie, żerujący rekin olbrzymi ma „bardzo szeroki otwór gębowy”21 i pływa tuż pod powierzchnią morza ,z szeroko otwartą paszczą, filtrując plankton”22, dlatego greckim żeglarzom i rybakom mógł przypominać lwa, którego ogromna, otwarta paszcza zawsze budziła grozę.

Po czwarte, starożytni Grecy i Rzymianie z pokładu statku mogli łatwo obserwować długoszpara, który żeruje na niewielkiej głębokości i „chętnie wygrzewa się przy powierzchni wody"23 (skąd bierze się jego kolejna, oboczna nazwa rekin słoneczny). $Z$ powodu łatwej rozpoznawalności i prostoty obserwacji rekin olbrzymi musiał być doskonale znany w świecie antycznym nie tylko rybakom, ale i żeglarzom.

Gigantyczne rozmiary długoszpara, ogromna, otwarta podczas żerowania paszcza i przypominające grzywę szczeliny skrzelowe przywodziły na myśl lwa

\footnotetext{
${ }^{21}$ Terofal, Militz 1996: 14.

${ }^{22}$ Terofal, Militz 1996: 14.

${ }^{23}$ Terofal, Militz 1996: 14.
} 
(Panthera leo L.), króla zwierząt lądowych ${ }^{24}$. Wygląd rekina olbrzymiego zawsze budził grozę i przerażenie, nic zatem dziwnego, że antyczni Grecy nazywali go „lwem morskim”. Tego typu skojarzenie nie było bynajmniej wyjątkowe. Jako ciekawostkę możemy przytoczyć fakt, że grafik czasopisma „Harper's Weekly" (w numerze z dnia 24 października 1868 r.) przedstawił wyrzuconego na brzeg morski rekina olbrzymiego z tylnymi lwimi łapami.

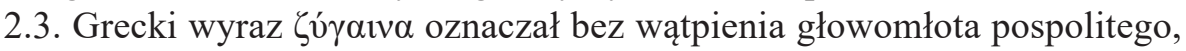
zwanego też rybą młotem lub rekinem młotem (Sphyrna zygaena L.) z rodziny młotowatych (Sphyrnidae) ${ }^{25}$. Ryba jest kosmopolityczna i często występuje w Morzu Śródziemnym ${ }^{26}$. Ani identyfikacja gatunkowa, ani etymologia nie bu-

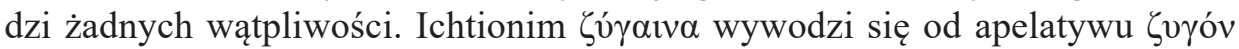
n. 'jarzmo', co jest motywowane wielce charakterystycznym kształtem czaszki głowomłota pospolitego przypominającym belkę jarzmową ${ }^{27}$. Leksem zawiera przyrostek - $\alpha \mathrm{iv \alpha}$, tworzący nazwy rodzaju żeńskiego, zwykle nazwy samic, np.

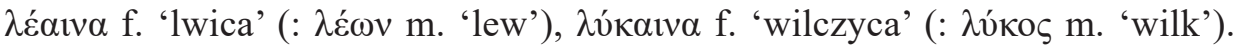
Nie ma zatem wątpliwości, że starożytni Grecy doskonale wiedzieli, że rekin młot jest rybą jajożyworodną. Ichtiolodzy podają, że „w miocie rodzi się 10-40 młodych mierzących w chwili urodzin 50-60 cm długości" ${ }^{28}$.

2.4. „Lampart morski” (gr. $\pi \alpha ́ \rho \delta \alpha \lambda ı \varsigma$ f.) został wymieniony dwukrotnie przez Klaudiusza Eliana: po raz pierwszy wśród morskich potworów w analizowanym przez nas rozdziale IX 49, po raz drugi w przytoczonym fragmencie dotyczącym potworów morskich żyjących w Oceanie Indyjskim (XVI 18). Także Oppian z Korykos wspomina to stworzenie w podobnym kontekście ${ }^{29}: \pi 0 \rho \delta$ ó $\lambda 1 \varepsilon \dot{\varepsilon} \varsigma$

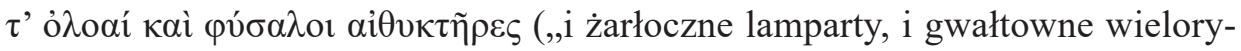
by"). Warto jednak zauważyć, że Oppian w poemacie dydaktycznym pt. Sztuka

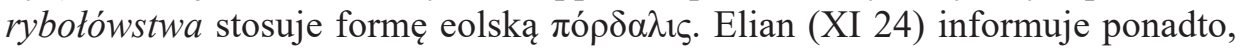

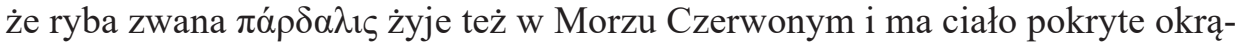

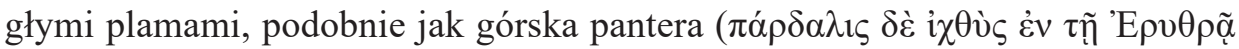

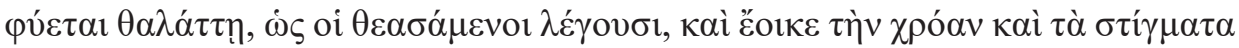

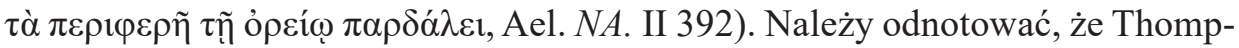

${ }^{24}$ Lew był relatywnie rzadko widywany na terenie antycznej Grecji. Występował jednak w starożytności na Półwyspie Bałkańskim, a także w Azji Mniejszej. Z lwem mogli zetknąć się także koloniści greccy, którzy osiedlili się w Egipcie i Cyrenajce. Wydaje się, że większość antycznych Greków znała lwa głównie z przedstawień oraz mitycznych opowieści, a nie z autopsji. Rzymianie mogli oglądać lwa na żywo podczas regularnie organizowanych igrzysk, na które sprowadzano z Afryki i Azji liczne okazy nieznanych w Europie drapieżników.

${ }^{25}$ Thompson 1936: 74-75; Dalby 2003: 299; Kokoszko 2005: 82-84; Chrone-Vakalopoulos, Vakalopoulos 2008: 144.

${ }^{26}$ Rutkowicz 1982: 140-141; Terofal, Militz 1996: 22-23.

${ }^{27}$ Strömberg 1943: 35; Beekes 2010: 502.

${ }^{28}$ Terofal, Militz 1996: 22.

${ }^{29} \mathrm{Za}$ wydaniem: Opp. H. I 368. 


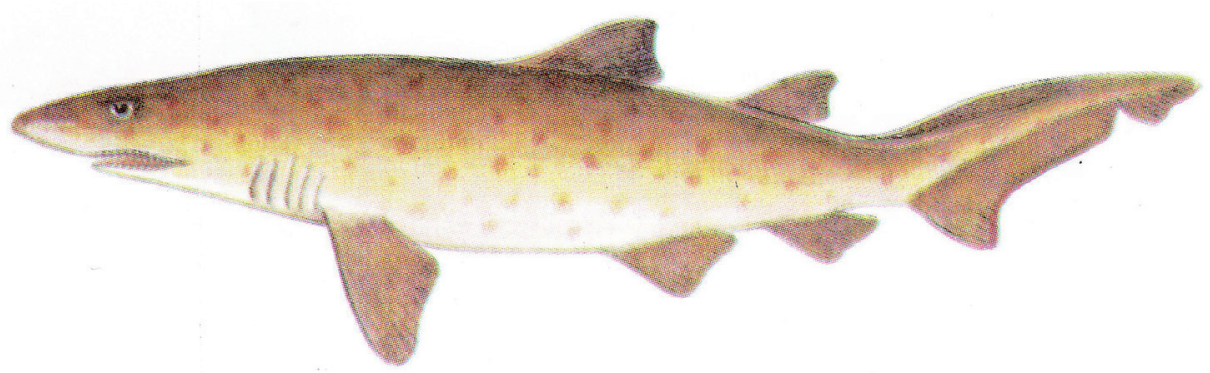

Ilustr. 2. Tawrosz piaskowy (Odontaspis taurus Rafinesque).

Źródło: Rutkowicz 1982: 130.

son nie ma pewności, czy „lamparty morskie”, żyjące w Morzu Śródziemnym i w Morzu Czerwonym, reprezentują ten sam gatunek ${ }^{30}$.

Ważkie argumenty pozwalają, naszym zdaniem, skojarzyć „lamparta morskiego" z tawroszem piaskowym (Odontaspis taurus Rafinesque, syn. Carcharias taurus Rafinesque, Carcharias arenarius Ogilby) z rodziny tawroszowatych (Ondontaspidae) ${ }^{31}$. Za powyższą identyfikacją przemawiają następujące przesłanki odnoszące się do (a) rozmiaru ryby, (b) jej występowania, (c) żarłoczności oraz (d) charakterystycznego ubarwienia.

Po pierwsze, tawrosz piaskowy jest dużą rybą jajożyworodną, mieszczącą

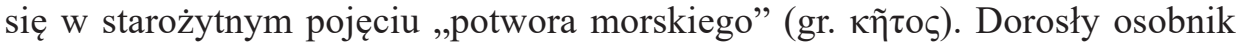
osiąga zazwyczaj trzy metry, maksymalnie dochodząc do $4,5 \mathrm{~m}^{32}$. Waga tawrosza może wynosić ok. $200 \mathrm{~kg}$.

Po drugie, ryba Odontaspis taurus (Rafinesque) występuje nie tylko w Morzu Śródziemnym, ale także w Oceanie Indyjskim i Morzu Czerwonym, co jest zgodne $\mathrm{z}$ doniesieniami Eliana ${ }^{33}$.

Po trzecie, tawrosz piaskowy jest rybą drapieżną o dużych, ostrych zębach, niezwykle żarłoczną i niebezpieczną, co zgadza się z informacją podaną przez

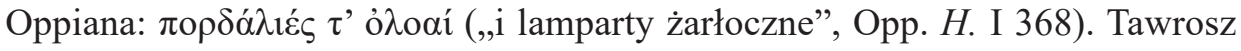
zwykle przebywa i poluje w głębinach morskich, ale podpływa też do wybrzeży i niekiedy atakuje kąpiących się ludzi. Tego typu ataki zdarzały się na pewno już w starożytności, więc niebezpieczny tawrosz piaskowy musiał być przez Greków doskonale rozpoznawalny.

Po czwarte, tawrosz ma szaropiaskowy grzbiet pokryty okrągłymi, ciemniejszymi brązowymi plamami (cętkami) rozmieszczonymi równomiernie na całym ciele. Bardzo podobne ubarwienie, jak sygnalizuje Elian, ma górska pantera,

\footnotetext{
${ }^{30}$ Thompson 1936: 104.

${ }^{31}$ Rutkowicz 1982: 130-131; Terofal, Militz 1996: 10-11.

${ }^{32}$ Rutkowicz 1982: 131.

${ }^{33}$ Vide za wydaniem: Ael. NA IX 49; XI 24; XVI 18.
} 
zwana zazwyczaj irbisem, panterą śnieżną albo śnieżnym leopardem (Pantera uncia Schreber).

Przedstawione argumenty przemawiają jednoznacznie za proponowaną identyfikacją „lamparta morskiego” z tawroszem piaskowym (Odontaspis taurus Rafinesque). Wydaje się, że żaden inny gatunek nie może wchodzić w rachubę ${ }^{34}$.

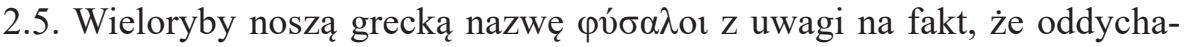
ją za pomocą płuc i wydmuchują wodę w górę za pomocą pryskawki (por. gr.

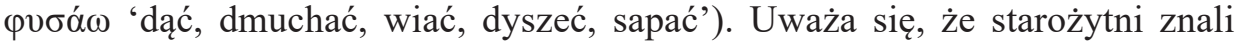
i rozpoznawali wieloryby występujące w Morzu Śródziemnym, zarówno fisz-

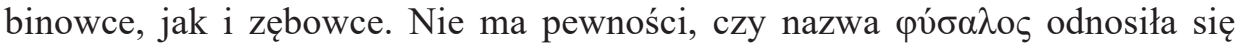
do wszystkich waleni, czy też do jednego konkretnego gatunku, np. do finwala (Balaenoptera physalus L.) ${ }^{35}$. Niektórzy badacze dopuszczają hipotezę, że starożytni Grecy określali tym apelatywem kaszalota a. potwala a. potwala olbrotowca (Physeter macrocephalus L.) ${ }^{36}$. Zarówno finwal, jak i kaszalot mógł być zaliczany do budzących strach monstrów morskich. Możliwe są jednak inne identyfikacje, np. wal Cuviera a. zyfia gęsiogłowa (Ziphius cavirostris Cuvier), grindwal (Globicela melas Traill) lub płetwal karłowaty (Balaenoptera acutorostrata Lacépède).

2.6. Piła a. ryba piła (gr. $\pi \rho \tilde{\sigma} \sigma \tau \iota \varsigma$ f.) 'Pristis pristis L.' to ogromna ryba jajożyworodna z rodziny piłowatych (Pristidae), występująca zarówno w Morzu Śródziemnym, jak i w Oceanie Atlantyckim ${ }^{37}$. Osiąga ona długość do $5 \mathrm{~m}$, ciężar do $600 \mathrm{~kg}$. Ryba piła jest łatwo rozpoznawalna z powodu niezwykłego wyglądu, gdyż charakterystyczny wyrostek na jej pysku przypomina piłę ${ }^{38}$. Nie jest

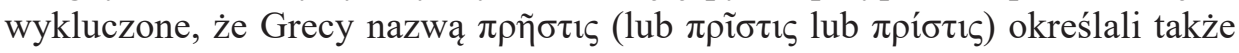
pokrewną rybę zwaną piłą drobnozębną 'Pristis pectinata Latham' ${ }^{39}$.

2.7. Stworzenie zwane „malthe” (gr. $\mu \alpha \dot{\lambda} \theta \eta$ f.) zostało wymienione przez Klaudiusza Eliana wśród morskich zwierząt o monstrualnych rozmiarach. Oppian z Korykos wymienia to samo stworzenie w identycznym kontekście, pod-

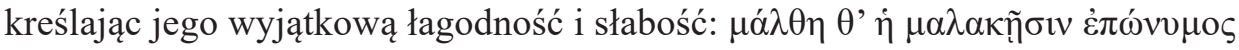

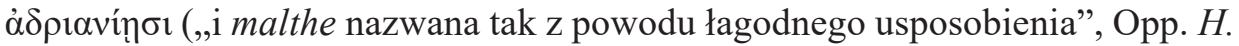
I 371). Elian charakteryzuje zwierzę w następujący sposób: $\delta v \sigma \alpha v \tau \alpha \gamma \omega ́ v ı \sigma \tau o v$

${ }^{34} \mathrm{Za}$ inną opcją opowiadają się Chrone-Vakalopoulos, Vakalopoulos (2008: 145). Greccy badacze proponują identyfikację z żarłaczem białym albo rekinem ludojadem (Carcharon carcharias L.), co nie przekonuje $\mathrm{z}$ dwu powodów. Po pierwsze, żarłacz biały nie ma plamistego ubarwienia. Po drugie, rekin ten nie występuje w Morzu Czerwonym.

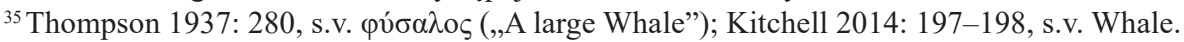

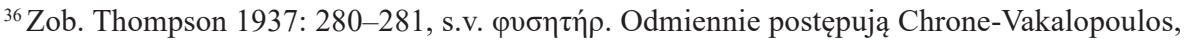

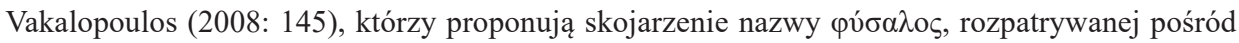
wielkich monstrów morskich, ze stornią (Platichtys flesus L.), niedużą rybą z rodziny flądrowatych (Pleuronectidae). Tego typu identyfikacja polega na oczywistym nieporozumieniu.

${ }^{37}$ Rutkowicz 1982: 146-147; Terofal, Militz 1996: 28-29.

${ }^{38}$ Strömberg 1943: 44.

${ }^{39}$ Thompson 1936: 219; Chrone-Vakalopoulos, Vakalopoulos 2008: 145. 


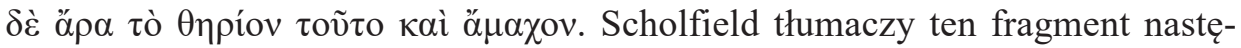
pująco: „This last animal is a terrible antagonist and invincible”"40 (,To ostatnie zwierzę jest straszliwym i niezwyciężonym przeciwnikiem"), co sugeruje agresywność opisywanego zwierzęcia i stoi w jaskrawej sprzeczności z opinią Oppiana. W naszym thumaczeniu proponujemy pojmowanie przymiotnika ớ $\mu \alpha \chi v$ w sensie aktywnym („niewalczące”). Uważamy, że łagodne usposobienie gigan-

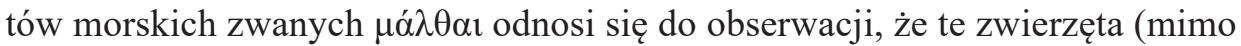
przerażającej wielkości) nie atakują ludzi, nie szkodzą łodziom rybackim, ani starożytnym statkom handlowym w przeciwieństwie do „baranów morskich”, które są wysoce niebezpieczne dla ludzi.

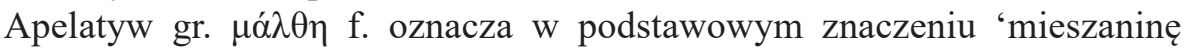
wosku i smoły'41, służącą w epoce antycznej do uszczelniania i impregnowania statków. Dzięki zastosowaniu tej substancji starożytne statki miały czarną barwę. Leksem $\mu \alpha \alpha \lambda \theta \eta$ (także $\mu \alpha \dot{\lambda} \theta \alpha \alpha$ ) został zapewne zapożyczony ze źródła semickiego, choć w historycznych językach tej rodziny potwierdzony jest przede wszystkim sens 'zaprawa murarska': hebr. melet 'polepa gliniana lub zaprawa murarska', syr. mlāțā 'zaprawa murarska', arab. milāt 'ts. ${ }^{42}$. Pamiętajmy jednak, że semiccy Fenicjanie, kiedy stali się narodem żeglarzy i kupców morskich, gruntownie rozwinęli sztukę szkutniczą i żeglarską. Wydaje się prawdopodobne, że zmiana semantyczna 'zaprawa murarska' > 'substancja uszczelniająca statki' dokonała się najpierw w języku fenickim, a dopiero stamtąd została przyjęta do języka greckiego. Można także przypuszczać, że nazwa czarnego impregnatu, powstałego z połączenia wosku i smoły, została przeniesiona przez żeglarzy greckich (i być może fenickich) na takie zwierzę morskie, które miało intensywnie czarne ubarwienie ${ }^{43}$. O jakie zwierzę morskie znacznych rozmiarów i żyworodne może chodzić?

Czarne ubarwienie mają dwa duże ssaki morskie, spotykane dawniej w Morzu Śródziemnym i w Oceanie Atlantyckim oblewającym Europę:

(I) Wieloryb (wal) biskajski (Eubalaena glacialis Müller, syn. Balaena glacialis Müller, Balaena biscayensis Eschricht) z rodziny wielorybów gładkoskórnych (Balaenidae) był niegdyś pospolity w Oceanie Atlantyckim i w zachodniej części Morza Śródziemnego. Ma on skórę o czarnej barwie; jedynie na brzuchu (zwykle niewidocznym, bo zanurzonym w wodzie) występuje jaśniejsza plama.

${ }^{40}$ Scholfield 1959: II 269. Podobnie Maspero (1998: 565): „e il pesce chiamato malta [?] che è un mostro terribile e molto periculoso".

${ }^{41}$ Abramowiczówna 1962: 71.

${ }^{42}$ Rosół 2013: 190. Autor negatywnie ocenia hipotezę zapożyczenia semickiego w języku greckim.

${ }^{43}$ Inaczej Strömberg 1943: 32. Autor uważa, że morski gigant zwany $\mu \alpha \dot{\lambda} \theta \eta$ został nazwany od miękkiego lub podobnego do wosku mięsa. Domysł ten wydaje się wątpliwy, skoro Klaudiusz Elian

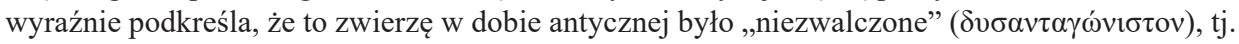
niedające się upolować. 
Są to wyjątkowe olbrzymy o masie 40-50 ton i długości 14-18,5 metra ${ }^{44}$. Pływają wolno i majestatycznie, żywiąc się planktonem. Nie są agresywne i dlatego w XII wieku stały się obiektem polowań podjętych przez Basków w Zatoce Biskajskiej. Na skutek intensywnych połowów wielorybniczych w wiekach XVIII-XX populacja wieloryba biskajskiego stała się nieliczna i w dobie współczesnej jest stale zagrożona wymarciem.

(II) Grindwal długopłetwy (Globicephala malaena Traill, syn. Globicephala melas Traill) jest kosmopolitycznym ssakiem drapieżnym z rodziny delfinowatych (Delphinidae), zamieszkującym północną część Atlantyku i nawiedzającym w porze zimowej zachodnią połać Morza Środziemnego z Morzem Jońskim włącznie ${ }^{45}$. Grindwale przypominają bardziej walenie niż delfiny. Mają czarne ubarwienie, jedynie spód ciała (zwykle niewidoczny) ma nieco jaśniejszy kolor. Grindwal długopłetwy jest mniejszy od orki (Orcinus orca L.), ale osiąga imponujące rozmiary: długość samic waha się w granicach 4,3-5 metrów, długość samców najczęściej dochodzi do 8,5 m. Masa ciała dorosłego osobnika wynosi od 2 do 3 ton. Grindwal żywi się głównie głowonogami, ale nie gardzi małymi rybami. Nie jest niebezpieczny dla ludzi.

Oba rozwiązania są teoretycznie możliwe do przyjęcia. Wieloryb biskajski jest łagodnym, choć blisko pięćdziesięciotonowym olbrzymem, którego nie sposób upolować tradycyjnymi (dostępnymi w starożytności) metodami. Z kolei grindwal długopłetwy, mimo znacznych rozmiarów, ma charakter zbliżony do delfinów, które były przez Greków uważane za zwierzęta mądre i przyjazne człowiekowi. Co więcej, grindwal, polujący głównie na głowonogi (zwłaszcza kałamarnice) oraz drobne ryby, nigdy nie rywalizował i nie rywalizuje z rybakami o połowy.

Wydaje się, że Oppian i Klaudiusz Elian pod pojęciem $\mu \alpha ́ \lambda \theta \eta$ rozumieli raczej łatwo rozpoznawalnego wieloryba biskajskiego, który charakteryzuje się intensywnym czarnym ubarwieniem, a także masywnymi zgrubieniami skóry na górnej szczęce, zwykle wystającej z wody. Trzecią cechą, dzięki której wielorybnicy i zoolodzy łatwo odróżniają wieloryby biskajskie od innych waleni, jest podwójny słup wody w formie litery $\mathrm{V}$, skierowany ku przodowi, pojawiający się każdorazowo przy wynurzaniu się. Wieloryb biskajski odznacza się wyjątkową łagodnością (co podkreśla Oppian) oraz ogromnymi rozmiarami (które w pojęciu Eliana - czynią go niezwyciężonym).

W swoim opracowaniu Klaudiusz Elian wprowadza zamierzony kontrast, mianowicie przeciwstawia stworzenie morskie zwane $\mu \alpha \dot{\lambda} \theta \eta$, trudne do pokonania z powodu samego ogromu (wieloryb biskajski ma masę 40-50 ton), ale bardzo powolne i zasadniczo nieagresywne (wieloryb biskajski żywi się planktonem), innemu potworowi morskiemu o opozycyjnym charakterze, mianowicie

\footnotetext{
${ }^{44}$ Reichholf 1996: 278-279.

${ }^{45}$ Reichholf 1996: 264-265.
} 


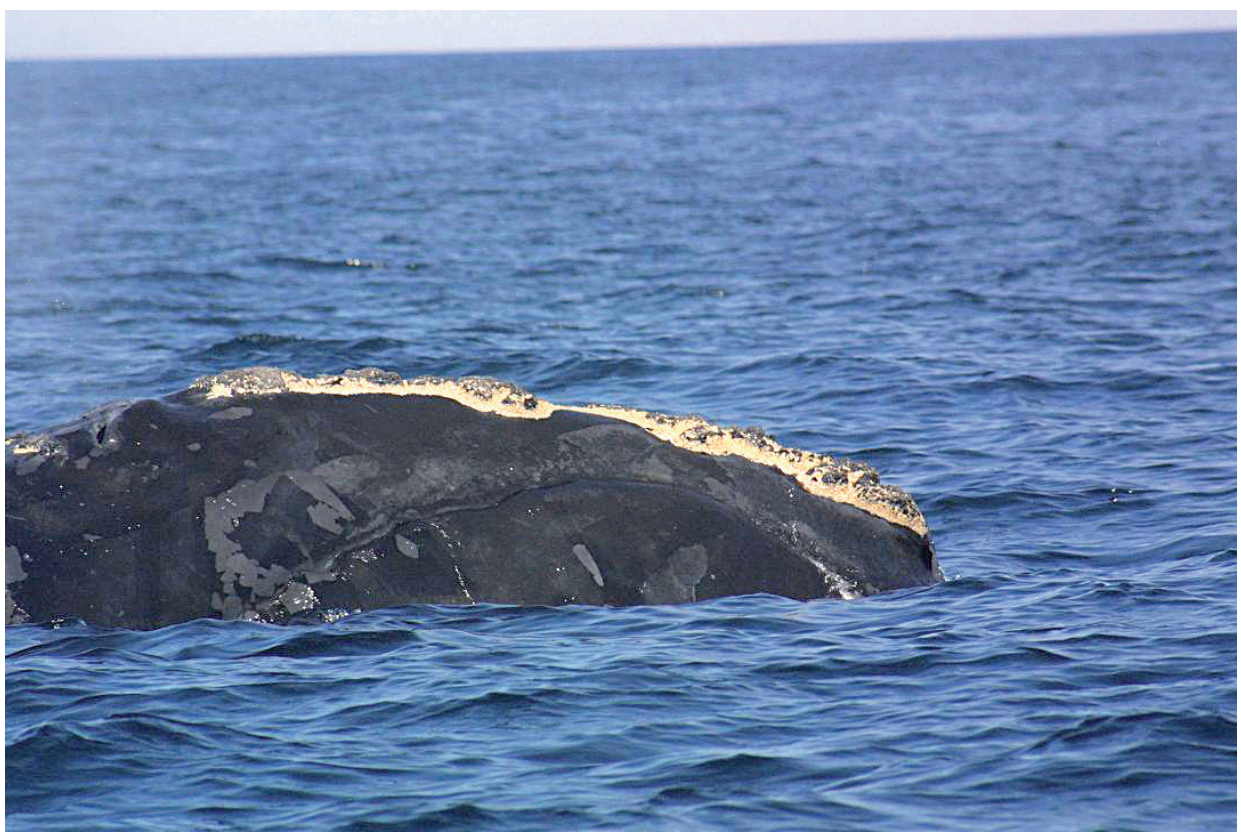

Ilustr. 3. Wieloryb biskajski (Eubalaena glacialis Müller) pływający w Oceanie Atlantyckim. Źródło: Wikimedia Commons. Domena publiczna.

drapieżnemu i agresywnemu, szybko pływającemu i bardzo niebezpiecznemu „baranowi morskiemu”.

2.8. „Baran morski” (gr. крı́́ $\mathrm{m}$.) jest wielce niebezpiecznym gigantem morskim, szczególnie groźnym dla rybaków. Thompson nie zdołał zidentyfikować jednoznacznie „barana morskiego" ${ }^{46}$. W innym fragmencie dzieła De natura animalium (XV 2) Elian rzeczowo przedstawia wygląd „barana morskiego”, który charakteryzuje się białymi plamami na czole i grzbiecie, a także opisuje strategię polowania „barana” na foki ${ }^{47}$. Z tej relacji jasno wynika, że Grecy sto-

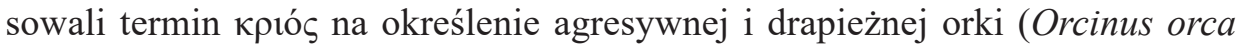
L. ${ }^{48}$. Zaobserwowano, że orki polując gromadnie świadomie wywołują wielkie fale, by przewrócić krę lodową, na której schroniła się foka ${ }^{49}$. Elianowy opis „barana morskiego" wskazuje na straszne i niebezpieczne zwierzę morskie, zarówno jeśli chodzi o rozmiary, jak i technikę polowań, która polega na wywoływaniu fal na skutek gwałtownego wynurzenia. Można przypuszczać, że antyczni

\footnotetext{
${ }^{46}$ Thompson 1936: 131-132 (,An unknown sea-monster”).

${ }^{47} \mathrm{Za}$ wydaniem: Ael. NA XV 2.

${ }^{48}$ Scholfield 1959: III 205.

${ }^{49}$ Zob. film dokumentalny ukazujący polowanie orek na leżącą na krze lodowej fokę, umieszczony na stronie internetowej: [https://www.cda.pl/video/6253bb.].
} 
rybacy, łowiący ryby na niewielkich łódkach, mogli być także obiektem ataków orek, czyli „baranów morskich”.

2.9. Wymieniona przez Klaudiusza Eliana „hiena” (gr. v̌aıva f.) to kolejny potwór morski niełatwy do zidentyfikowania. Zdaniem Thompsona, „hiena morska" reprezentuje ,a fierce and monstrous, but unknown, fish" ${ }^{50}$. Pisarz z Praeneste podkreśla jedynie, że już sam widok „hieny morskiej” stanowi nie-

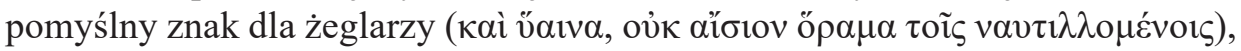
co jednoznacznie wskazuje, że owa tajemnicza „hiena” była z daleka widoczna na powierzchni morza. Oppian wskazuje z kolei na wyjątkowe rozmiary „hieny

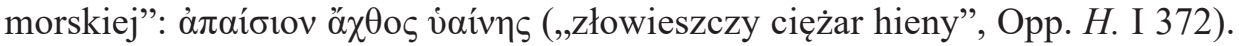
Wielkość i ogromna waga potwora morskiego, a także jego skojarzenie z hieną, wydaje się wskazywać na jakiegoś walenia z grupy zębowców. Wydaje się, że „hieną morską" mógł być nazwany kaszalot spermacetowy, zwany także potwalem olbrotowcem (Physeter macrocephalus L.). Kilka przesłanek mogłoby przemawiać za taką identyfikacją. Po pierwsze, dorosły kaszalot osiąga masę ciała od 30 do 50 ton, co zgadza się z informacją Oppiana o wielkim, „złowieszczym ciężarze hieny". Po drugie, kaszalot ma masywną głowę w stosunku do reszty ciała, podobnie jak hiena pręgowana (Hyaena hyaena L.). Po trzecie, wielki garb kaszalota przypomina do złudzenia wygięty grzbiet hieny. Nie ma jednak bezspornych dowodów na to, że skojarzenia antycznych Greków były tożsame w tymi przesłankami, dlatego identyfikację „hieny morskiej” pozostawiamy jako nierozstrzygniętą.

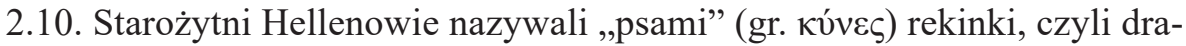
pieżne rekiny mniejszych rozmiarów ${ }^{51}$, należące do rodziny rekinkowatych (łac. Sciliorhinidae). Głównymi przedstawicielami tej rodziny, występującymi w Morzu Śródziemnym, są: rekinek psi (Scyliorhinus canicula L.), rekinek plamisty a. rekinek panterka (Scyliorhinus stellaris L.) oraz piłogon (Galeus melostomus Rafinesque-Schmaltz) ${ }^{52}$. Klaudiusz Elian omawia trzy gatunki „psów morskich” w rozdziale 55 pierwszej księgi dzieła De natura animalium ${ }^{53}$. Ponieważ owa opowiastka została wcześniej przetłumaczona przez prof. Annę Marię Komornicką $^{54}, \mathrm{w}$ niniejszej rozprawce poświęconej zupełnie innej partii dzieła Eliana (NA IX 49) rezygnujemy z rozważań dotyczących identyfikacji poszczególnych gatunków śródziemnomorskich rekinków.

\footnotetext{
${ }^{50}$ Thompson 1936: 272.

${ }^{51}$ Thompson 1936: 136-137.

${ }^{52}$ Terofal, Militz 1996: 16-19. W okresie późnoantycznym i bizantyńskim Grecy określali

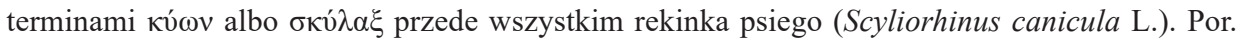
Chrone-Vakalopoulos, Vakalopoulos 2008: 134.

${ }^{53}$ Za wydaniem: Ael. NA I 55.

${ }^{54}$ Komornicka 2005: 38-39.
} 


\section{KONKLUZJE}

W niniejszym opracowaniu poddano analizie semantyczno-etymologicznej występujące w relacji Klaudiusza Eliana (De natura animalium IX 49) nazwy

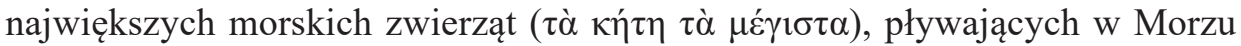
Śródziemnym i Oceanie Atlantyckim. Podjęto także próbę identyfikacji owych potworów morskich. Analiza dostępnych danych filologicznych oraz zoologicznych doprowadziła do zaproponowania nowych identyfikacji:

3.1. Grecka nazwa $\lambda \dot{\varepsilon} \omega v$ (dosłownie ,lew”) określała rekina olbrzymiego (Cetorhinus maximus Gunnerus).

3.2. Ichtionim $\pi \alpha ́ \rho \delta \alpha \lambda \imath \varsigma$, rzadziej $\pi$ ó $\delta \alpha \lambda \imath \varsigma$ (dosłownie ,lampart”) odnosił się zapewne do groźnego drapieżnika atakującego także ludzi - tawrosza piaskowego (Odontaspis taurus Rafinesque).

3.3. Niezwyciężony gigant morski zwany $\mu \alpha ́ \lambda \theta \eta$ to zapewne wieloryb biskajski, zwany też walem biskajskim (Eubalaena glacialis Müller).

W artykule przychylono się także do niektórych zgłoszonych wcześniej sugestii, np.:

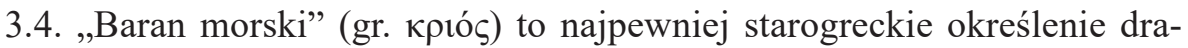
pieżnej orki (Orcinus orca L.).

W artykule przedłożono także hipotetyczną, lecz możliwą do zaakceptowania identyfikację ,hieny morskiej” (gr. v̋ , $\alpha$ ) z kaszalotem spermacetowym lub potwalem olbrotowcem (Physeter macrocephalus L.).

\section{BIBLIOGRAFIA}

Teksty źródłowe, przekłady, komentarze:

Aelian, On the Characteristics of Animals, with an English translation by A.F. Scholfield, vol. II-III, London-Cambridge (MA) 1959.

Aelian, La natura degli animali, vol. I-II, ed. F. Maspero, Milano 1998.

Oppian, Cynegetica et Halieutica, ed. I.G. Schneider, Lipsiae 1813.

Svidae Lexicon, edidit A. Adler, pars III, Stuttgartiae 1967.

Opracowania:

Abramowiczówna 1958-1965: Z. Abramowiczówna (red.), Słownik grecko-polski, vol. I-IV, Warszawa 1958-1960-1962-1965.

Adler 1967: A. Adler (ed.), Svidae Lexicon, pars III, Stuttgartiae 1967.

Beekes 2010: R. Beekes, Etymological Dictionary of Greek, vol. I-II. Leiden-Boston 2010.

Chrone-Vakalopoulos, Vakalopoulos 2008: M. Chrone-Vakalopoulos, A. Vakalopoulos, Fishes and Other Aquatic Species in Byzantine Literature: Classification, Terminology and Scientific Names, „Byzantina Symmeikta” 18 (2008), 123-157.

Dalby 2003: A. Dalby, Food in the Ancient World from A to Z, London-New York 2003.

Jurewicz 2000: O. Jurewicz, Stownik grecko-polski, vol. I, Warszawa 2000.

Kitchell 2014: K.F. Kitchell, Animals in the Ancient World from A to Z, London-New York 2014.

Kokoszko 2005: M. Kokoszko, Ryby i ich znaczenie w życiu codziennym ludzi późnego antyku $i$ wczesnego Bizancjum (III-VII w.), Łódź 2005. 
Komornicka 2004: A.M. Komornicka, w: Klaudiusz Elian, Nowe ciekawostki o zwierzętach, przełożyła A.M. Komornicka, „Meander” 59.5-6 (2004), 392-403.

Komornicka 2005: A.M. Komornicka, w: Klaudiusz Elian, O wtaściwościach zwierząt (wybór), przeł. i oprac. A.M. Komornicka, Warszawa 2005.

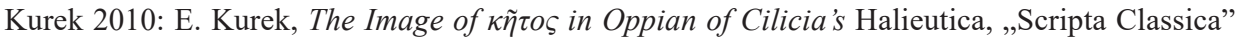
7 (2010), 55-62.

Liddell, Scott 1996: H.G. Liddell, R. Scott, A Greek-English Lexicon, with a revised supplement, Oxford 1996.

Maspero 1998: F. Maspero (ed.), Claudio Eliano, La natura degli animali, vol. I-II, Milano 1998. Montanari 2003: F. Montanari, Vocabolario della lingua greca, Milano 2003.

Reichholf 1996: J. Reichholf, Ssaki. Leksykon przyrodniczy, tłum. H. Garbarczyk, E. Nowakowski, Warszawa 1996.

Rosół 2013: R. Rosół, Frühe semitische Lehnwörter im Griechischen, Frankfurt am Main 2013.

Rutkowicz 1982: S. Rutkowicz, Encyklopedia ryb morskich, Gdańsk 1982.

Schneider 1813: I.G. Schneider (ed.), Oppiani Cynegetica et Halieutica, Lipsiae 1813.

Scholfield 1959: A.F. Scholfield (transl.), Aelian, On the Characteristics of Animals, vol. II-III, London-Cambridge (MA) 1959.

Strömberg 1943: R. Strömberg, Studien zur Etymologie und Bildung der griechischen Fischnamen, Göteborg 1943.

Terofal, Militz 1996: F. Terofal, C. Militz, Ryby morskie. Leksykon przyrodniczy, przekład i adaptacja H. Garbarczyk i E. Nowakowski, Warszawa 1996.

Thompson 1936: A.W. Thompson, Glossary of Greek Fishes, London 1936.

\section{ANCIENT GREEK NAMES OF LARGE SEA ANIMALS \\ IN THE LIGHT OF AELIAN'S TESTIMONY (DE NATURA ANIMALIUM IX 49)}

\section{Sum mary}

The article explains chapter IX 49 of Aelian's De natura animalium, concerning the Ancient

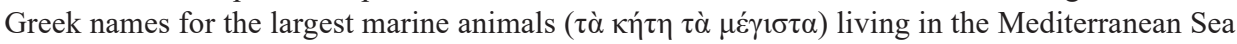
and the Atlantic Ocean, i.e. in the seas surrounding Southern and Western Europe. An attempt is made to identify certain sea monsters; the analysis of the available philological and zoological data leads to the suggestion of several new identifications. Firstly, it is surmised that the Greek word $\lambda \varepsilon \dot{\varepsilon} \omega v$ (literally 'lion') should be identified as the basking shark (Cetorhinus maximus Gunnerus). Secondly, the big fish called $\pi \alpha \dot{\alpha} \rho \delta \lambda \lambda \iota_{\varsigma}$ (literally 'leopard') seems to represent the sand tiger shark (Odontaspis taurus Rafinesque). Thirdly, the invisible sea giant called $\mu$ ó $\lambda \theta \eta$ in Greek (hence Lat. maltha) refers to the North Atlantic right whale (Eubalaena glacialis Müller). 